e-makâlât Mezhep Araştırmaları, VII/1 (Bahar 2014), ss. 261-265.

ISSN 1309-5803 | www.emakalat.com

\title{
KELÂMÎ MEZHEPLER VE FIRKALAR
}

Ali Rabbânî Gülpâyigânî, Önsöz Yayıncılık, İstanbul 2014

456 sayfa,

\section{Adem Sezgin UZUN ${ }^{1}$}

İslam Mezhepleri Tarihi ve Kelam birbirleriyle yakından ilişkisi olan iki İslâmî disiplindir. Bu yakın ilişkiyle beraber metodolojileri birbirinde farklıdır. Kelam, İslam düşüncesini zaman ve mekândan bağımsız olarak ele alırken İslam Mezhepleri Tarihi, İslam düşünce tarihini fikir-hadise, zaman-mekân bağlamında ele alır. Günümüzde Kelam ve İslam Mezhepleri Tarihi alanlarında modern çalışmaların sayısı artıyor. Bu artışta ilahiyat fakültelerinin sayısının ve kontenjanının artmasının etkisi göz ardı edilemez. Bu açıdan Kelam ve İslam Mezhepleri Tarihine yönelik giriş seviyesinde bilgi edinme taleplerinin karşılanabilmesi için yeni yeni çalışmalar yapılmaktadır. Bu çalışmalardan birisi de Ali Rabbânî Gülpâyigânînnin orijinal adı "Fırak ve Mezâhib-i Kelâmî" olan ve Türkçemize "Kelâmî Mezhepler ve Fırkalar" ismiyle tercüme edilen kitabıdır. Eser Sedat BARAN tarafından Farsçadan Türkçeye kazandırılmış ve Önsöz Yayınc1lık tarafından 2014 yılında yayımlanmıştır.

Ali Rabbânî Gülpâyigânî 1955 yılında İsfahan'da doğdu. Eğitimine Kum medreselerinde devam etti. Ayetullah Tebrizî, Ayetullah Sübhanî gibi Kum'un önde hocalarından ders aldı. Aynı bölgenin tanınan hocalarından biri oldu. Nitekim tanıtacağımız bu kitap, Ali Rabbânî Gülpâyigânî'nin Kum medreselerinde İslam Mezhepleri Tarihi derslerinde ders kitabı olarak okutulmaktadır.

\footnotetext{
${ }^{1}$ İ.Ü. İlahiyat Fakültesi İslam Mezhepleri Tarihi Araştırma Görevlisi
} 
Kitap medrese usulü okutulduğundan/okutulacağından olsa gerek konular tek seferde işlenecek dersler halinde bölünmüş. Toplamda elli yedi dersten meydana gelmektedir. Bu elli yedi ders de altı bölüme ayrılmıştır.

Eser bir giriş ve altı bölümden oluşmaktadır. Birinci bölüm (s. 13-38) "Giriş" olup ilk beş dersi kapsıyor. Burada İslam Mezhepleri Tarihi ve Kelam'ın temel kavramları olan "Milel ve Nihal" kavramlar1, yetmiş üç fırka hadisi ve İslam tarihinde ortaya çıkan ilk ihtilaflar ele alınmıştır. İslam mezheplerinin genel bir tasnifi yapılmış ve Selef'in kelam yöntemine değinilmiştir.

İkinci bölüm (s. 41-182) on yedi dersten oluşmaktadır. Yazar, bu bölümde, Şîa fırkalarını incelemiş; Şîa'nın isimlendirilmesine değinmiş, Şîa fırkaları hakkında genel bilgi verdikten sonra İsmâiliyye, Fatımîler, Karmatîler, Zeydiyye ve İmâmiyye firkalarını ele almıştır.

Üçüncü bölüm (s. 185-270) on iki dersten oluşmaktadır. Bu bölümde yazar, Ehl-i Sünnet’i ele almıştır. Bu çerçevede Ehl-i Sünnet kavramının ortaya çıkışını, Ehl-i Hadis ve Hanbelîler, Selefiyye, İmam Ebû Musa el-Eş'arî ve Eş'ariyye, Eş'arîyye'nin önde gelen âlimleri, İmam Mâturîdî ve Mâturîdiyye hakkında bilgi vermiştir. Ayrıca bu bölümde yazar, Mâturîdiyye ve Eş'ariyye'nin karşılaştırmasını yapmış ve önde gelen Maturîdi âlimlere yer vermiştir.

Dördüncü bölüm (s. 273-337) dokuz dersten oluşmakta olup "Diğer İslamî Mezhepler ve Fırkalar" adını taşımaktadır. Bu bölümde yazar Kaderiyye, Mutezile, Mürcie, Havâric, Cehmiyye firkalarını ele almıştır. Bu fırkaların ortaya çıkışları, tarihi gelişimleri, alt fırkaları ve günümüzdeki durumları hakkında bilgi vermiștir.

Beşinci bölüm ( s.341-386) yedi dersten oluşmaktadır. Yazar bu bölümde Gâlî fırkaları ele almış; bu çerçevede "Gulât" kavramının anlamı, kimlere Gulât denileceği gibi hususlarda bilgi verdikten sonra Dürzîler, Nusayrîler, Ehl-i Hakk, Şeyhiyye ve Keşfiyye, Bâbiyye ve Bahâiyye, Kâdiyâniyye ve Ahmediyye firkaları hakkında ayrı ayrı bilgiler vermiştir.

Altınc1 ve son bölüm (s. 389-422) ise yedi dersten oluşmaktadır. $\mathrm{Bu}$ bölümde yazar, İslam Mezhepleri Tarihi ve Kelam 1stılahında birden fazla mezhep için kullanılan ortak kavramlar hakkında bilgi 
vermiştir. Bu çerçevede Haşeviyye ve Râfıza, Adliyye, Tefvîz ve Müfevviza, Te'vîl ve Müevvile, Sifâtiyye ve Muattıla, Müşebbihe ve Mücessime, Tafdîliyye ve Vaîdiyye kavramlarını ele almış ve bu kavramların kimler için kullanıldığı hakkında bilgi verilmiştir.

Eser, Sunuş'ta belirtildiğine göre, İran'ın Kum şehrindeki medreselerde İslam Mezhepleri dersinde okutulmak üzere kaleme alınmıştır. Bu açıdan konular ders ders olarak tasnif edilmiştir. Yazar, Mürcie ve Gulât gibi kendisince önemsiz gördüğü konuları kısa tutmuş ve yeri geldiğinde hatalı gördüğü noktaları belirtmiştir (s. 307). Mürcie ve Gâlî firkalar İslam tarihinde izleri günümüze ulaşan etkiler bırakmışlardır. Mürcie iman-amel ilişkisi konusundaki görüşleriyle İslam düşüncesinde iman konusunda yeni bir bakış açısı getirmiştir. Ehl-i Sünnet büyük günah işleyen kişinin kâfir olmayacağ1 konusunda Mürcie'den etkilenmiştir. Günümüzde de Müslümanların büyük bir kısmı buna inanmaktadır. Gâlî firkalar ise $\mathrm{Hz}$. Ali, tecsim, teşbih, nübüvvet konularındaki görüşleriyle İslam dünyasında o zamana kadar görülmeyen görüşler ileri sürmüşlerdir. Bu görüşleri nedeniyle zamanın yöneticileri tarafından takibe uğramışlar ve tekfir edilmişlerdir. Bu açıdan İslam düşünce tarihinde önemli etkileri olmuş bu iki fırka daha ayrıntılı ele alınabilirdi. Özellikle Gâlî fırkaların Şia'yla ilişkisi üzerinde daha fazla durulabilirdi.

Kitap akademik yönden bazı problemlere sahip. Bazı alıntıların kaynağ1 yok ve genelde ikinci el kaynaklara atıf yapılmış. Örneğin yetmiş üç fırka hadisi aktarılırken kaynak olarak Cafer Sübhânî'nin "Buhûs fi'l-Milel ve'l-Nihal"i gösterilmiştir. Oysa ilgili rivayetin tahrici yapılabilir ve özellikle Şii hadis literatüründe olup olmadığı belirtilebilirdi. Şehristânî'den yapılan bir alıntının (s. 30) kaynağı verilmemiş. Yine başka bir yerde (s. 36) Selef'in akaid yöntemi aktarılırken hangi eserlerin dikkate alındığı belirtilmemiştir. Yazarın klasik kaynaklardaki bilgiler arasinda tercih yaparken tercih sebebini belirtmemesi dikkati çekmektedir (s. 315).

Yazar yer yer ciddi eleştirilerde bulunmuş, ancak bu eleştirilerin dayanağını zikretmemiş. Örneğin Osmanlı Devleti'nin Şiilere (s. 6566) ve Nusayrilere (s. 356) zulmettiğini, onları mezhep değiştirmeye zorladığını söylemiş, ancak buna dair bilgi veya belge ortaya koymamiştır. 
Yazar, ele aldığı mezheplerin sonuç kısmında İmamiyye ekolünün konu hakkındaki görüşünü vererek okuyucuya bir kıyaslama yapma imkanı vermiş olmakla birlikte, konuların işlenişinde İmamiyye anlayışını merkeze aldığını da hissettirmektedir. Bazı ayetlerin manaları Şii-İmâmî doktrine uygun olarak verilmiş. Örneğin Âl-i İmrân suresi 7. ayette geçen "Onun tevilini ancak Allah bilir. Ilimde derinleşmiş olanlar..." ifadesini "Onun tevili ancak Allah ve ilimde derinleşmiş olanlar bilir." şeklinde tercüme edilmiş (s. 403). Bu tercüme imamların gaybi bilgileri bilebileceği şeklindeki Şii-İmami doktrine uygundur.

Yazar kitapta Şii-İmamî kaynaklara ve Kum medreselerindeki diger hocaların eserlerine bol bol atıflarda bulunmuştur. Bu kitaplar İslam Mezhepleri Tarihine kaynak olabilmeleri açısından sonraki dönemlere ait olduğu için bu atıflar kitabın akademik değerine gölge düşürmüştür. Örneğin İsmaililer'e dair "Nübüvvet ve İmamet'in Mertebeleri" konusu anlatılırken Henry Corbin'in "Târih-i Felsefese-i Der İslami” isimli kitaba atıf yapılmıştır. Halbuki konuyla alakalı olarak ilk dönem İslam Mezhepleri Tarihi eserlerinde fazlaca malumat bulunmaktadir.

Metot açısından esere bakıldığında konuların İslam Mezhepleri Tarihi metodundan daha çok kelamcıların metoduyla yazıldığı görülmektedir. $\mathrm{Bu}$ bağlamda görüşlerin çoğu defa zamandan ve mekândan bağımsız olarak aktarıldığına şahit olmaktayız. Ancak bazı yerlerde ilgili fırkanın ilk ortaya çıkışı ve teşekkül süreci hakkında da bilgi verilmiştir.

Kitabın sunuş bölümünün sonunda imza bulunmamaktadır. Muhtemelen bu kısım, yayınevi tarafından yazılmıştır. Ayrıca kitabın çevirmeni Sedat Baran hakkında da bilgi verilmemiştir. Eserin ilk baskısı Şubat 2014'te yapılmış olup elinizdeki değerlendirme de bu baskıya aittir. Eserde bazı tercüme hataları göze çarpmaktadır. Eserin yeni baskılarında bu hataların giderileceğini umuyoruz. Örneğin İbn Hazm bir yerde (s. 16) İbn Cezm, Malatî "Multî", tecsim "tescim" olarak yazılmıştır. Arapça ifadelerin transkripsiyonunda da bazı hatalar var. Bu hatalar, tercümenin sahasında uzman bir kişi tarafından tashih edilmediğini göstermektedir. Umarız daha sonraki baskilarda bu hatalar giderilir. 
"Kelâmî Mezhepler ve Fırkalar" adlı bu eser, günümüz İran'ında İslam Mezhepleri Tarihinin nasıl anlaşıldığ 1 ve pratikte nasıl okutulduğu hususunda bizlere önemli bilgiler sunmaktadır. Bu eser sayesinde, Şii-İmami geleneğin mezhepleri nasıl tasnif ettiği, usul ve metotlarının mahiyeti ve nihayetinde zihniyetlerinin niceliği hususlarında sağlıklı bilgiler sunmaktadır. Ayrıca yazarın Şii-İmami kaynaklara atıf yapması, bize, klasik ve modern dönem Şii-İmami kaynakları hakkında daha fazla bilgi sahibi olma imkânı vermektedir. 
